\title{
The Politics of Fiscal Decentralization in Ghana: An Overview of the Fundamentals
}

\author{
Samuel S. Ankamah ${ }^{1}$ \\ ${ }^{1}$ School of Public Administration, Hohai University, Nanjing, China \\ Correspondence: Samuel S. Ankamah, School of Public Administration, Hohai University, No1 Xikang Road, \\ 210098, Nanjing, China. Tel: 86-1-589-598-6870. E-mail: ankamah_s@yahoo.com
}

Received: September 3, 2012 Accepted: September 19, 2012 Online Published: October 18, 2012

doi:10.5539/par.v1n1p33 URL: http://dx.doi.org/10.5539/par.v1n1p33

\begin{abstract}
Fiscal decentralization has gained support by most of the world's leading development organizations including the World Bank, United States Agency for International Development and, Asian Development Bank among others in the last two to three decades. It is therefore of much importance that some form of thought is given to the operations of this system to make it more beneficial. Drawing selectively on large academic and practical literature on fiscal decentralization and the articles in this volume, this article outlines the state of fiscal decentralization in current times. It then goes on to outline some key arguments in favor of and against fiscal decentralization as a system of government. The theoretical framework of fiscal decentralization is also discussed in this article with regards to the stabilization, distribution and allocation functions. An overview of this system of government so far as Ghana is concerned has also been touched on with much emphasis on the legal framework and the key sources of finance for subnational governments. Finally, a number of factors for improving and making this system more beneficial and sustainable over time are identified.
\end{abstract}

Keywords: Fiscal Decentralization, Central Government, Sub-national Government, Local Capacity, Ghana

\section{Fiscal Decentralization}

“...The establishment of effective and transparent financial management is at the core of any effort to reform the public sector...To be genuinely supportive of a decentralization process, the basic characteristics of a system for decentralized financial management should include: (a) transparency of allocation, (b) predictability of the amounts available to local institutions and (c) local autonomy of decision making on resource utilization. In contrast with the widespread practice of ad hoc grants driven by politics, the allocation of resources should be based on transparent formulas. Also, unlike the typical unpredictability of most central-to-local transfer mechanisms prevailing in developing countries, the process should provide local institutions with an up-front indication of how much money will be available in the next multiyear planning cycle. This makes local strategic planning possible and provides a financial ceiling that makes such planning a meaningful exercise and an opportunity for local communities to take autonomous decisions on the use of limited resources" (UN, 1996).

Fiscal decentralization is seen as a government system which involves the "assignment of responsibilities" comprising of the functions and activities at the various sectors of government as well as the assignment of locally generated revenues to local/subnational governments (Smoke, 2003). Fiscal decentralization has become the main issue in the decentralization process of which Ghana is no exception and it includes externally and internally generated sources of revenue. It has become very important for subnational governments in their quest to achieve their desired development goals and objectives at the local level (Dick-Sagoe, 2012). Fiscal decentralization has gained support by the world's leading development agencies including the World Bank, USAID, the Asian Development Bank among others, making it "part of a world-wide reform agenda." It has therefore played a major role in the formulation of economic, development and governance strategies in developing and transitional economies (Bahl, 1999a). The World Bank iterates that some 68 developing countries out of a number of 75 in the mid 1990s practiced some form of fiscal decentralization. The World Bank therefore sees fiscal decentralization and craves for local discretion and devolution of power as a major force shaping governance and development in these current times of globalization (World Bank, 1997). In his analysis of some 58 countries in the early 1990s, Oates (1993) also demonstrated a more cordial and positive relationship between economic growth and fiscal decentralization and suggests some role for subnational governments 
especially in infrastructure development.

Kee (2003) therefore outlines some three basic reasons that has propelled the "renewed interest" in fiscal decentralization as a reform in many countries in this current times;

(1) Central governments are increasingly finding that it is impossible for them to meet all of the competing needs of their various constituencies as well as local areas and are now attempting to build local capacity by the delegation of responsibilities to their regional subnational governments.

(2) Central governments are looking to local and regional governments to assist them on "national economic development strategies".

(3) Regional and local political leaders are demanding more autonomy and want the taxation powers that come along with the associated expenditure responsibility.

In as much as fiscal decentralization encourages the devolution of resources, it does not only involve the transfer of resources to different levels of government. According to UNDP (2005), fiscal decentralization is also about how local governments are given more power to have "authority and control" in the use and management of their financial resources. This according to the UNDP is seen in their control over;

(1) The provision of the basket of local services for which they are responsible;

(2) The level of local taxes and revenues (base, rates, and collection);

(3) The grant resources with which they finance the delivery of local public services.

"Ghana's decentralization process provides a framework for a system of locally-controlled development and planning. By this process, district assemblies were established and charged as the local planning authorities with responsibility for the overall development and governance of their district of jurisdiction" (Dick-Sagoe, 2012). This has made the District Assemblies in Ghana to be at heart of the service delivery, development and democracy at the subnational levels of Ghana. It can be said therefore that, the exact nature of fiscal decentralization and intergovernmental fiscal decentralization policy differs from one country to another depending on how subnational governments and administrators are organized. The design of fiscal decentralization policy for any country and subnational structures should therefore begin with a strong recognition of the benefits and the cost of this governance model. The first and most beneficial argument according to Musgrave should be the gains of moving government closer to the people since this is the most efficient argument that drives the thinking of most economists (Musgrave, 1983).

\section{Arguments in Support of Fiscal Decentralization}

In theory, the case for fiscal decentralization can be traced to the "17th and 18th century philosophers, including Rousseau, Mill, de Tocqueville, Monstesquieu and Madison" (Kee, 2003). However, the modern case for this governance phenomenon was uttered by Wolman. In his theory, he divided the proponent arguments under two headings: "Efficiency Values and Governance Values.

\subsection{Efficiency Values}

In his opinion, "efficiency is an economic value seen as the maximization of social welfare". Thus in the regulation of supply and demand, the price signals of the public sector differs from that of the private sector. The public sector mainly allocates goods and services on political lines; notwithstanding, the package of tax services should be in line with the "aggregate preferences of community members" (Wolman 1997, cited in Kee, 2003). Moreover, the demand and preference of citizens in any political area for services differs from one person to the other in terms of size and number. In view of this therefore, there is a "divergence between the preferences of individual community members and the tax and service packages reflecting the aggregate community preferences" (Ibid). Kee (2003) therefore reiterate the fact that, "since such divergence reduces social welfare", it would be more favorable to hold those to a minimum and this will make them marginal in local areas "than in larger, more heterogeneous areas (the nation)".

\subsection{Governance Values}

To Wolman, "governance values include responsiveness, and accountability, diversity, and political participation" (Wolman 1997, cited in Kee, 2003). Thus to Wolman, in order to promote greater "responsiveness" of local officials with its associated greater "accountability" to citizens, decentralization places much emphasis on allocation decision making to be closer to the people. This is because local decision makers are expected to be informed with the problem and needs of their areas of jurisdiction as compared to their centralized counterparts (Ibid). Also, according to Kee (2003), accountability through local elections for example "is more likely driven 
to issues of local allocation whereas national elections are seldom focused on local service delivery".

According to Tiebout (1956), diversity in public policy is another argument for fiscal decentralization in the sense that it offers citizens a greater choice in public services and tax options when they want to decide on where to settle. This serves as a platform of innovation for both local and national governments in making future implementation decisions. However, there is much pressure on central government to make its policies as uniform as possible even though no theory prevents it from being diverse in this regard.

In the view of Kee, fiscal decentralization is seen as a model that promotes democratic participation at the sub national levels of government. It provides a platform for local decision making on development planning and implementation priorities and has the "potential to enhance democratic values and political stability at the local level" (Kee, 2003).

\section{Criticisms of Fiscal Decentralization}

In as much as the call by international development agencies for fiscal decentralization has been strong over the years due to its perceived enormous advantages; other scholars including Tanzi and Prud'homme have also criticized this governance model especially in relation to its adoption in developing countries.

Tanzi (1995) raises a number of situations where fiscal decentralization may lead in one way or the other to less than an optimal result and these include:

(1) Taxpayers may have insufficient information or no political power to pressure local policy makers to make resource-efficient decisions.

(2) Local politicians may be more corrupt than national politicians or at least find themselves in a more corrupting situation.

(3) The quality of bureaucracies is likely to be better than local bureaucracies.

(4) Technological chance and increased mobility may reduce the number of services that are truly "local" in nature.

(5) Local governments often lack good public expenditure management systems to assist them in their tax and budget choices.

(6) Fiscal decentralization may exacerbate a central government's ability to deal with "structural fiscal imbalances".

Prud'homme (1995) also finds some shortfalls of the fiscal decentralization model. He suggests that fiscal decentralization be adopted in countries where there are roughly even regional capacities. However, this situation is not common in many countries especially in developing countries. Moreover, the redistribution of national income should be by the central government and not the sub national government. This is as a result of the fact that, it can lead to the poor in developed and higher income regions to be better off than their counterparts in the less developed and low income areas. Also in regions where the policy is to impose higher taxes on the rich and redistribute to the poor, the rich might migrate to areas where the tax policy favors them making the poor in such areas to be poor for good making the model "self defeating". In addition, it may lead to a "destructive competition" among regions to attract investors by way of "lowering their taxes and improving subsidy". Prud'homme further argues that the motive behind decentralization of revenues is not the same as expenditure; and "in many cases the problem is not so much in whether a certain service should be provided by a central, regional, or local government, but rather how to organize the joint production of the services by the various levels".

However, McClure (1995) in one way or the other addressed the concerns of Prud'homme's argument based on pure fiscal decentralization and that is where the shortfall comes in; insisting that decentralization not done correctly is likely to cause some problems. He argues that there is nothing like pure decentralization as put forward by Prud'homme and therefore iterates that, it is rather some functions that are decentralized. He however agrees with Prud'homme that central government should retain sufficient revenue for effective stabilization and redistribution roles.

\section{The Framework of Fiscal Decentralization Theory}

The "proper" distribution of tax authority and expenditure responsibility is a far complex issue, making economists to generally focus on issues of "efficiency and equity" whereas public administration and political science scholars also tend to shift their focus on the " distribution of powers, responsiveness and accountability, and tax competition and coordination (Kee, 2003). Musgrave's framework for analyzing roles or functions is 
widely accepted. Thus referring to the standard and Musgrave model of public sector responsibility for stabilization, distribution and allocation, the decentralization theory helps in the direction and sharing of these functions among different levels of government (Musgrave, 1959).

\subsection{The Stabilization Function}

The stabilization function according to Musgrave looks at the role the tax and spending policies of government as well as the monetary policy play in the management of the whole level of economic activity. It has been argued therefore that this function which is entirely made up of macroeconomic variables be assigned to the national government to undertake. The central government in the performance of this function should however, have a broad-based tax suitable for the task. Thus although the macroeconomic environment of the international economy has changed in many ways, this gives rise to questions as to whether this function should still be retained with the central government (Smoke, 2001). It is however not difficult to justify stabilization as a central function in developing countries. Thus the macroeconomic fluctuations in developing countries can be very severe. Local governments in developing and transition economies often have a marginal role in the national economy and the local revenue situation in such countries can be very "problematic" (Ibid).

\subsection{The Distribution Function}

The distribution function as stated by Musgrave involves the part government plays in changing the distribution of income, wealth or other indicators of economic wellbeing so as to make them more equitable than would have been the case. In retaining this function with the national government, two assumptions are made; (a) that the national government's broad taxing powers can more easily redistribute income and; (b) that the ability of taxpayers to move from one jurisdiction to another in order to take advantage of more attractive spending and taxation policies weakens local government's ability to "soak the rich and redistribute to the poor". Moreover, local resource bases are often limited as are the expenditure role of local authorities as well as their capacity to administer major redistribution programs.

\subsection{The Allocation Function}

The role of local governments in the allocation function is of great importance since it is not likely for the demand of public services and goods to be uniform across space. It is however the decision of the government on the mix of public and private goods that the economy provides. The allocation function proposes the argument that, each level of government may be more efficient in the delivery of a particular public good or service and for that matter that subnational level should be made to provide that service. For example in the provision of security or national defense and health, it is of the belief that the national level should be the provider as is the likelihood that certain services including fire and police protection will be more suitable at the local level. In matching local revenue to expenditure in the allocation process therefore, economist give much preference to efficiency, vertical imbalances (mismatch between revenue and expenditure), horizontal equity (fiscal capacity among regions), externalities (spillovers) and tax exportation. In allocating a function to the local government with respect to revenue, (Oates 1972, cited in Smoke, 2001) suggests four basic guidelines;

(1) Making local taxes as neutral as possible in terms of their effect on economic behavior;

(2) Making the benefits and costs of local taxes clear to those for whom services are to be provided;

(3) Making pattern of incidence of local taxes to meet equity standards and;

(4) Making administration and compliance cost to be as minimal as possible by avoiding the assignment of complex taxes to local governments.

According to Kee (2003), the framework is of much importance in thinking about the type of taxes that should be levied at each level of government as well as its accompanying tax authority. Thus a level of government to which some function has been allocated should have the monetary capacity to undertake that function effectively and efficiently. In the view of Kee therefore, if tax collection or fiscal capacity falls short expenditure responsibilities, that level of government should be given additional taxing authority or revenue mobilization power or rely on intergovernmental transfers such as grants and shared taxes to support its expenditure.

\section{Overview of Fiscal Decentralization in Ghana}

Decentralization as well as fiscal decentralization in Ghana started in the late 1870s when the British Government established the indirect rule which lasted until 1951. During this period, the colonial administration ruled the people of Ghana indirectly through the chiefs by making the chiefs and elders in given districts as the local authorities, with powers to perform local government functions (Crawford, 2004). During this period of colonial rule, decentralization was attributed to mere de-concentration of the central government administrative 
structure, where the colonial used this means to strengthen its power and control over the entire nation. Thus decentralization became a political tool for the British through the local chiefs and their elders to reemphasize on the wishes of colonial government (Antwi-Boasiako, 2010).

According to Antwi-Boasiako, even after independence in 1957, many studies described the era of decentralization during this time as not effective. This according to him was with reference to the fact that, change through military coups became the order of the day after Kwame Nkrumah was overthrown in 1966 (Ibid). It was during the mid 1970s under the Lt. Col. Ignatius Kutu Acheampong's military era that the government tried as much as possible in her efforts to empower the local people (Nkurmah, 2000).

However, the 1992 constitution, following over a decade of military dictatorship under Jerry John Rawlings (1981-1991) provided a paradigm shift from military rule to multi-party democracy (Antwi-Boasiako, 2010). Prior to the bringing into force of the constitution was the comprehensive local government reform that was initiated 1988 by the PNDC government, intended to transfer functions, powers, means, and competences from the central government to the local government. It can be said therefore that, Ghana's decentralization policy from 1988 to date brings to light, elements of political, administrative and fiscal decentralization among other factors that seek to promote good governance and accountability as has already been stated in the introduction of this report. Ghana's commitment to decentralization is embodied emphatically in the 1992 constitution as well as other legislative instruments and has been the policy of various successive governments over the years. The goals of the decentralization program according to Ghana (2008) are to: strengthen and expand local democracy; promote local, social and economic development; and to reduce poverty and increase the choices of the people.

Ghana's decentralization as a government system encompasses three main facets that are commonly related as has been put forward by White (2011) which includes:

(1) De-concentration: thus the process whereby the central government disperses responsibilities for certain services to regional branch offices without any transfer of associated authority. According White, many scholars do not consider this as true decentralization;

(2) Delegation: this refers to a situation in which the central government transfers responsibility for decision making and administration of public functions to subnational governments. Here, local governments are accountable to central governments but are not controlled fully by the central governments; and

(3) Devolution: this happens when the central government transfers authority for decision making, finance, and administrative management to quasi autonomous units of local government.

To white, it seems that most recent literature consider devolution to be the purest or at least the most extensive form of decentralization. In sharing her view, Ayee (1996) iterates that Ghana's approach to decentralization appears to place much emphasis on devolution which involves the transfer of power to Metropolitan, Municipal and District Assemblies (MMDAs) and given the absolute autonomy and associated responsibility to determine the level of services required, the best methods to ensure their provision and the sources and type of funds to finance such services efficiently and make them more effective.

\subsection{Legal Framework}

Decentralization and for that matter fiscal decentralization in Ghana has a strong legal environment that seek to promote and ensure its succession over the years. In the Article 35 (6d) of the 1992 constitution, it states that the state shall make democracy a reality by decentralizing the administrative and functional machinery of government to regions and districts and by affording all possible opportunities to the people to participate in decision-making at every level in national life and in government. The objectives and composition of decentralized subnational governments have since been laid in out in the chapter 20 of the 1992 constitution.

In Article 240 ( 1 and 2e), it states that local government and administration be decentralized as far as practicable and that the functions, powers, responsibilities and resources be transferred from the central government (castle) to the local government (constituents). The independent role of the local government with discretionary powers at the grass root level is also made known in article 240(b). This article proposes measures to be taken to enhance the capacity of local government authorities to plan, initiate, coordinate, manage and execute policies with regards to matters affecting the local people. With respect to the principle of participation and accountability, article 240 (2e) clearly states that, to ensure accountability of local government authorities, people in particular local government areas shall, as far as practicable be afforded the opportunity to participate effectively in their governance.

Other legal instruments that seek to strengthen decentralization and for that matter fiscal decentralization in Ghana include: 
(1) Local Government Act, 1993 (Act 462),

(2) Local Government Service Act, 2003 (Act 656),

(3) National Development Planning (Systems Act) 1994 (Act 480),

(4) District Assemblies Common Fund Act, 2003 (Act 455),

(5) Public Procurement Act, 2003 (Act 663),

(6) Audit Service Act, 2000 (Act 584),

(7) Internal Audit Agency Act, 2003 (Act 658),

(8) Financial Administration Act, 2003 (Act 654),

(9) Financial Administration Regulations, 2004 (LI 1802).

Other international legal binding of Ghana's commitment to decentralization that also promotes fiscal decentralization among others according to Ghana (2010) includes:

(1) Victoria Falls Declaration (1999) on an African Vision on Decentralization

(2) The Kigali Declaration (2005) on Leadership Capacity Building for Decentralized Governance and Poverty Reduction in Sub-Sahara Africa

(3) Commitment under the New Partnership for Africa's Development (NEPAD)

(4) Commitments under the Commonwealth Local Governance Forum declarations/affirmations which includes;

1) The Singapore Declaration,

2) The Harare Declaration,

3) The Millbrook Action Program,

4) The Latimer House Principles,

5) The Aberdeen Principles and,

6) Trinidad and Tobago Affirmation.

\subsection{Subnational Government Financial Composition}

Section 240 (2c) of the Local Government Act, 1993 (Act 462) and the constitution of the Republic of Ghana (1992), Section 245(b) provides that each local government unit shall have a sound financial base with adequate and reliable sources of revenue. "Despite this requirement the District Assemblies (DAs) have a limited number of sources of revenue for carrying out their activities, which include the District Assembly Common Fund (DACF), grants, transfers, cede revenues and external credits, land rates and minerals royalties and other Internally Generated Revenue (IGR)" (Dick-Sagoe, 2012). The sixth schedule of the local government act, 1993 (Act 462) again lists revenue sources of local governments to include; entertainment duty, casino revenue, betting tax, income tax registration of trades, gambling tax, rates and levies, fees, licenses, taxes chargeable on incomes of certain category of self employed persons and other miscellaneous receipts. For the purposes of this paper, IGF and DACF as sources of financing DAs among others were considered.

\subsubsection{Internally Generated Funds (IGF)}

The authority to generate revenues from the district has its legal backing from the 1992 constitution in Article 245(b) and the local government act 462 in sections 34, 50, 60, 74, 76, 85, 86, 94, 95 and 99 which empowers the assemblies to raise internal revenue to finance their development. IGFs are revenues that are directly generated by the DAs within their areas of jurisdiction. These are the only revenues among others that the Das have absolute control over its usage as well as the areas to be used. IGFs normally consist of rates, lands, fees and fines, license, rent and investment income among others. With regards to fiscal decentralization, the more revenues DAs can generate, the more power and autonomy they will have.

However according to Ghana (2008), DAs face some challenges with respect to own-source (IGF) revenue mobilization and these include:

(1) The land valuation board does not have adequate resources to carry out its responsibility to consistently value and revalue properties; (2) Many DAs do not have adequate databases and those that even do have are not able to maintain them properly; (3) House and street numbering has not been completed consistently throughout the country; (4) Leadership and support from the central government has been weak over the years; (5) There has not been any benchmarking to determine the level of IGF collections to total revenue received by DAs that would be 
appropriate; (6) Assembly members, staff and citizens of some DAs do not appreciate the importance of IGF revenue mobilization and the relationship between taxes paid and services provided; (7) There has been poor collaboration and understanding within the Assemblies between different players and actors to ensure internal control systems are strong and leakages kept to a minimum and to implement prudent tax policies.

There is therefore the need for DAs in the midst of these challenges to devise strategies and practices which will work best for them while still providing the drive to ensure that they are serious about increasing their IGF collections.

\subsubsection{District Assembly Common Fund (DACF)}

The District Assemblies' Common Fund (DACF), also referred to as the common fund, is a statutory arrangement backed by the 1992 constitution of Ghana in article 252(1and 2) and the District Assemblies Common Fund act, 2003 (act 455). Thus there shall be a fund to be known as the District assemblies common fund of which parliament shall annually make provisions for the allocation of not less than $5 \%$ (currently $7.5 \%$ ) of the total revenues of Ghana to the district assemblies for development and of which the amount shall be paid into the DACF in quarterly installment. The DACF is the source of funds mainly geared towards the finance of capital projects. In principle, there is no control on the use of the funds but in practice, guidelines are issued which in turn limits the freedom of the DAs (Appiah et al, 2000). The distribution of the fund is therefore based on the recommendation of the administrator of the fund which has to be approved by parliament before disbursement to the DAs can proceed (Osei-Akoto et al, 2007). According to Fynn (2011), the five main factors that are applied in sharing the fund among the districts include:

(1) Equality: this ensures that the assemblies have access to specified funds. It involves a straight forward division of a portion of the fund by the total number of DAs in Ghana; (2) The Need Factor is meant to address the current imbalances in development. It involves health, education, water and road indicators; (3) The responsive factor is also meant to motivate the DAs to generate and collect more revenue; (4) The service pressure factor is to assist in improving existing services, which as a result of population pressure are deteriorating faster than predicted; (5) The reserve factor is an outright deduction before the formula is applied. This reserve includes: Members of Parliament (MPs) fund, Regional Coordinating Councils (RCCs), Reserve (Contingency and Monitoring).

Below is a table showing the amounts of money deposited into the fund over the past decade:

Table 1. DACF Allocation From 2000 - 2010

\begin{tabular}{cc}
\hline Year & Allocations GH $\varnothing$ (Million) \\
\hline 2000 & 18.87 \\
2001 & 18.87 \\
2002 & 26.54 \\
2003 & 64.86 \\
2004 & 85.72 \\
2005 & 70.19 \\
2006 & 139.16 \\
2007 & 173.34 \\
2008 & 217.01 \\
2009 & 188.57 \\
2010 & 340.40 \\
Total & 1343.53 \\
\hline
\end{tabular}

Source: Fynn, K. (2011).

It is worthy therefore to note that DACF has been a key source of funding for the DAs in Ghana over the last decade and still continues to make massive contribution to the financing of the development of the various DAs in the country with deposits increasing from year to year. In the year 2000, the total amount of money deposited 
into the fund to be shared to the district amounted to GH $\notin 18.87$ million which increased to GH $\notin 340.40$ million in the year 2010 representing a percentage increase of $1703.9 \%$. however, the disbursement of the common fund is characterized. The system of allowing all government's revenues to be paid into the consolidated fund before the statutory payment to all areas including the DAs is a major source of delay in the release of the common fund. Prudent and realistic measures must therefore be proposed by policy makers and stakeholders effectively implemented to enhance the effective and efficient use of the fund for local development fiancé.

\section{Conclusion}

This paper has covered a considerable scope so far as fiscal decentralization is concerned as well as an overview of this system of government in Ghana. I am of the view therefore that, making decentralization a generic phenomenon can be an enemy of this system especially in least developed and economies in transition. Fiscal decentralization can be a very important asset for local development especially when the economy, politics, fiscal and institutional context and space within which it is to be employed is considered since these parameters vary from one space to another. Smoke (2001) therefore argues that "before thinking about fiscal decentralization, consideration must be given to the appropriate role of the public sector in a particular case". Thus even if the economic, political and institutional parameters are conducive for its operation, it must be borne in mind that such a system will not attain success easily and rapidly. He therefore outlines some essentials of a good fiscal decentralization program which includes: an adequate enabling environment; assignment of an appropriate set of functions to local governments; assignment of appropriate set of local own-source revenues to local governments; the establishment of an adequate intergovernmental fiscal transfer system; and the establishment of adequate access to local governments to development capital.

In drawing my conclusion, I would like to share the view of Smoke (2001) that three major "prerequisites" must be in place to optimize the potential long-term benefits of this phenomenon; (a) there must be viable local political mechanism that will help determine the local needs and "preferences" and also to make the local government "accountable" to their constituents, (b) subnational governments should have the institutional, technical and managerial capacity in serving the needs of their constituents and, (c) local governments must have access to the financial resources they need and require to meet their responsibilities. There is therefore the need for policy makers in Ghana to define creative ways in increasing the financial base and revenue envelope of subnational governments so as to cushion them in their bid to ensure local economic development and poverty reduction within their areas of jurisdiction.

\section{Acknowledgments}

The author is much grateful to the editor and anonymous reviewer for remarks on an earlier version of this paper. I am also thankful to Gloria Appiah-Sefah, Albert Adu-Gyamfi and Desmond Ofosu Anim for their constructive comments and continual encouragements in making this piece a reality. I am also much grateful to Dr. Yao Fen, James Oleche Oleyiblo and Professor Li Mang for their advice in my academic life which has also contributed in making these pieces a reality. I am finally grateful to the librarians of Hohai University for their support.

\section{References}

Antwi-Boasiako, K. B. (2010). Public administration: Local government and decentralization in Ghana. Journal of African Studies and development, 2(7), 166-175.

Ayee, J. R. A. (1996). A new look at the funding of local government in Ghana. A research review, 2(1), 2-5.

Bahl, R. (1999). Fiscal Decentralization as Development Policy. Public Budgeting\& Finance, Summer.

Crawford, G. (2003, October 23-24). Democratic decentralization in Ghana: issues and prospects. Norwegian association for development research (NFU) annual conference. Oslo, Norway.

Dick-Sagoe, C. (2012). Survey of literature of fiscal decentralization as a sustainable local development tool in Ghana. Journal of sustainable development in Africa, 14(3), 228-251.

Fynn, K. (2011). District Assemblies Common Fund (Our Common wealth). Joint decentralization review mission, ministry of local government/EU delegation to Ghana. Retrieved September 11, 2012, from www.commonfund.gov.gh/publication/EU Delegation to ghana.pdf

Kee, J. E. (2003, October 28-31). VIII International Congress of CLAD on State Reform and Public Administration. Panama.

McLure, C. E. (1995). Comment on "The Dangers of Decentralization" by Prud'homme. The World Bank Observer, 10(2), 221-227. 
Ministry Of Local Government And Rural Development, Ghana. (2008). Intergovernmental Fiscal Decentralization Framework. Issued by Ministry of Local Government, Rural Development and Environment. Accra.

Ministry Of Local Government And Rural Development, Ghana. (2010). Accelerating decentralization and local governance for national development. Draft decentralization policy framework issued by ministry of local government and rural development. Accra.

Musgrave, R. (1959). The Theory of Public Finance. New York: Mcgraw Hill.

Musgrave, R. A. (1983). Who Should Tax, Where, and What? In C. McLure (Ed.), Tax Assignment in Federal Countries. Canberra: Australian National University.

Oates, W. (1972). Fiscal Federalism, Harcourt, Brace, Jovanovich. New York.

Oates, W. E. (1993). Fiscal Decentralization and Economic Development. National Tax Journal, 46(2), $237-243$.

Prud'homme, R. (1995). The Dangers of Decentralization. The World Bank Research Observer, 10(2), $201-220$.

Smoke, P. (2001). Fiscal Decentralisation in Developing Countries: A Review of Current Concepts and Practice. Democracy, Governance and Human Rights Program Paper, No. 2. Geneva: United Nations Research Institute for Social Development.

Smoke, P. (2003). Decentralization in Africa: Goals, Dimensions, Myths and Challenges. Public Administration and Development, 23, 7-16. http://dx.doi.org/10.1002/pad.255

Tanzi, V. (1995). Fiscal Federalism and Decentralization: A Review of Some Efficiency and Macroeconomic Aspects. Paper prepared for the Annual World Bank Conference on Development Economics. Washington, DC: World Bank.

Tiebout, C. M. (1956). A Pure Theory of Local Expenditures. Journal of Political Economy, 64, 416-424.

UN (DDSMS and UNDP). (1996, September 23-27). Report of the United Nations Global Forum on Innovative Policies and Practices in Local Governance. Gothenburg, Sweden.

UNDP. (2005). Fiscal decentralization and poverty reduction. Retrieved August 27, 2009, from http:/unpan1.un.org/intradoc/groups/public/documents/un/unpan030970.pdf

White, S. (2011). Government decentralization in the 21st century. A report of the CSIS program on crisis, conflicts, and cooperation. Centre for Strategic and International studies.

World Bank. (1997). World Development Report: The State in a Changing World. New York: Oxford University Press. 